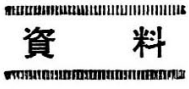

\title{
船舶 向きの腐食計測用プローベ*
}

\author{
D. Roller**, W. R. Scott**, H. S. Preiser*** \& F. E. Cook****
}

緒

言

造船界は多年外板の腐食と戦ってきた。防食塗装，す ぐれた材料，電気防食などの努力がずいぶん払われてい る。その効果は結果を見て判定するのが通例であるが， 従来の方法では確かめることができない特定の場所の腐 食で，しかもその量を数值的に確かめることが重要とな る問題がなおいろいろとある。

船体外板の腐食に比べると内側の腐食は比較的等閑視 されているが, Capp と Philibert1) は船体外板の腐食 注定期検查で発見されるため, 途中で船の運行に支障を 生ずるような腐食はまずないが，重大な内側の腐食が見 落されていたために船体や構造物に著しい障害を招いた 例は少なくないと述べている。タンク，ビルジ，外板， ロンジ,フレームなどは往々にして激しい腐食を受け る。高湿度, 乾湿の繰り返し, 塩分の残存, 妥当を欠く 設計や加工, 誤った材料の組合せ, 粗野な取り扱い, 気 まぐれな保守などが非常に腐食し易い環境をもたらすこ とがある。

船内で腐食障害の程度を判定する主な方法は肉眼検査 である。超音波厚み計がときには役に立つこともある。 時間の関係や近寄り難い場所の関係で検査は港内やドッ ク内に限定されることが多い。しかし肉眼検査は定性的 判断にすぎず，超音波測定も感度や識別力が不足する。 発見し難い重大な腐食障害が見逃されることが往々あ る。

重量変化を計測する方法は，その場所に計量した試験 片を取り付け，時々取り外して錆を落として計量する必 要がある。航海中には実行が面倒であり，試験期間中に どのような変化をしているか，変化の速度に変りはない かなどを確かめることもできない。

このように船内で航海中も腐食を测定することはなか なかむずかしい。これが簡単に，しかも遠隔測定ができ れば好都合であるが，電父抵抗法ならその可能性があ る。ここに述べるプローべ（試験片）はこの方法を使っ て工夫したものである。

腐食測定に電気抵抗法を利用した文献 ${ }^{2 ~ 7) ~ は い ろ い る ~}$

* 訳者: 花田政明 (日本防蝕工業)

* Magna Products Research \& Developments

*** Chemical Engineering Laboratories, Inc.

**** Bureau of Ships

(原交) Corrosion Measuring Probes for Marine Applications. Corrosion, Vol. 17, No. 10, $485 \mathrm{t} \sim 491 \mathrm{t}$ (1961) Oct.
とあり，船舶用に適する下記の長所を備えている。

1）試験片の大きさや形を大抵の場所に適合するよう 変えることができる。

2) 侵され残存金属の量を直接測る方法であるか ら，読み取った値は塗装・錆・污れ，または他の防食材 料の影響を受けない（これらは金属に比べてはるかに電 導度が低い)。

3）試験片を取り付けたままで, 電気的に計測でき る。

4) 金属の厚さを $\mu$ in 単位で直接読み得る。

これらの長所は, 舶用としての若干の欠点を十分補っ て余りあるものである。重量变化法は平均值を示すだけ で激しい孔食は正確には示さない。しかし電気抵抗法で は試験片の形状さえ妥当ならば十分正確に示す。またあ とから肉眼観察を加えることも できる。電気抵抗法でも対照す る試験片の塗装がいたんだり， 応力腐食のため䛊差を生ずるこ とはあるが，船舶用ではまず起 こらない。

このような考え方に立って, 米海軍ではいろいろの電気抵抗 法による腐食試験用プローベを 試作した。本論文はその設計, 構造就び予備実験の結果の大 要を述べたものである。

プローベは船体用 2 形式, 復 水器管用 1 形式, 円盤形 1 形式 の 3 種である。特長などは検討 の項に述べる。

\section{船体用プローベ}

これは船体用以外にも使える 一般的な設計になっている。同 一鉄板から切り取った腐食試験 片と比較用試験片とをエポキシ 樹脂で土台板（鉄板）に貼りつ け腐食試験片の腐食面以外はす ベて補強プラスチックで包み, ちょうど金属板とプラスチック のサンドウィッチのようになっ たしつかりした構造のもので激
図 1 船体内部用 試験片

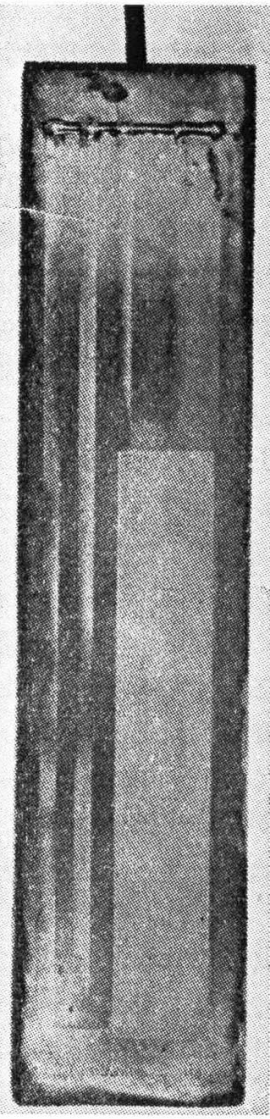


しい環境にも十分耐える。

叙装の優劣の実地試験にも役立てるためこの試験片は サンドブラストやケサギに耐えるだけの顓丈さが要求さ れた。精度や信頼性などの性能は防食対策で影響を受け なかった。この試験片は付近船体部分の腐食を代表でき る大きさでなければならなかった。長期の試験に腐食が 激しいため途中で切れたりなくなったりしないことも必 要であった。リード電線注成形直前に試験片につなき， 海水が浸透しないよう固めた。

この一般楧造で好きな大きさのものを造ることができ る。一方向または二方向に数 $\mathrm{ft}$ の寸法のものも造り得 る。最大寸法法成形装置の大きさから俳限されるだけで ある。船体腐食計測用に短冊形と平円板形の二つの一般 形を工夫した。図 1 の短册形は油タンク，バラストタン クボイド (空空) などに向くもので，士台板の四隅に 取り付けボルト穴がある。リード線に注耐水圧端子を設 けこれれから䆃いた電線を船体や隔壁に設けたパッキン ・グランドを通して大父中に取り出すことができる。

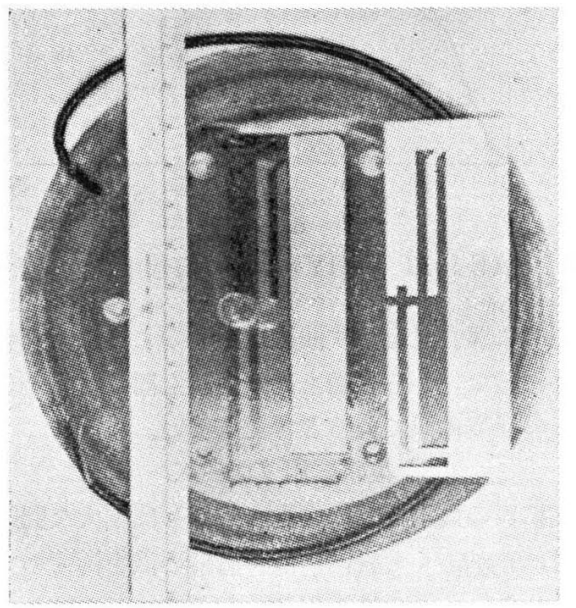

図 2 船体外板用試験片（鋳込前の测定片を添えて）

図 2 の平门板形注船体外板用で船体外板防食用標準陽 極と同一寸法の外径 $(13.5 \mathrm{in})$ と同じ寸洁の装備板があ り全厚約 $1 / 2$ in である。隅角はそいで水流の乱れを防 いだ。取付ボルト穴は 6 個で,リード線は裏から直接船 体を貫通することも，船体に添って平行溥くこともで きる。

\section{船体用プローベの試験とその評価}

最初に鋼とエポキシを重权合わせたものが，空気を含 む海水中で使用に耐えるか否かを確かめるため，海水中 に浅く浸したり，ポンプで泿み上げた海水をいるいろの 角度で試験片に当てたりした。図 3 はこの作動状況を示 すもので流速は約 $5 \mathrm{ft} / \mathrm{sec}$ である。

静水浸渍 2 週間で試験片の全面に多少の錆が出た。時 には縁の部分に喰い込みの出たものもあった。これは徹

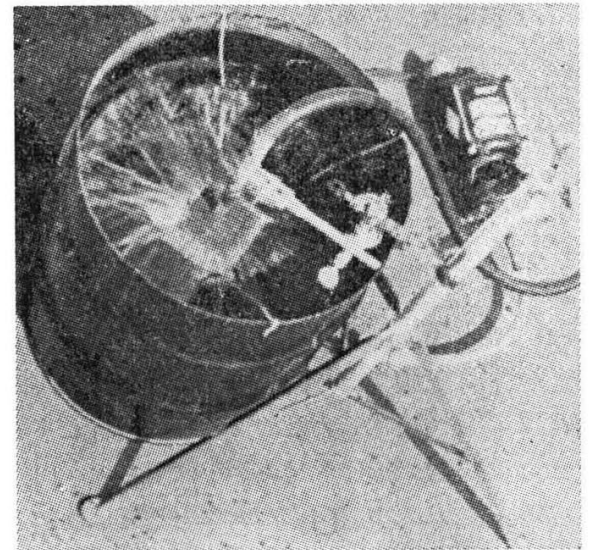

図 3 海水喷流試験設備

底的な仓成樹㝜の確究を行なう以前であったた的金属と 絶緑材料の密着不十分によるものであった。

高流速の噴流試験は通例 7 日問実施した。多くの場合 大部分の表面に黑く硬い酸化鉄の脱ができ，比較的わず かな部分が活発に腐食されて光沢のある金属面を示し た。試験片の一般構造には通例なえらの支障はなかっ た。適当な接着剂を見つけた後は金属部の喰い込みは認 められなくなった。

実際の海中譍食で当面する条俳をまねた他の試験方法 も試みた。最初の目的は実際の使用状沉でも層状試験片 がその物理的性質を害せずに維持できるかどうが確か めるにあった。その一種としてタンク内の海水中で試験 片を取り付けた円板を高速で回転させて, 試験片が高速 の海水に耐えるか否かを確かめたものがある。図4 に示 すようにタンクは試駼片に比べると非常に大きなもので ある。円板には数種の形式の船体用に適当と思わ礼る試 験片を取り付けて，その周速は $50 \mathrm{kt}$, 中央部の圾験片 を取り付けた部分の周速は約 $25 \mathrm{kt}$ になるようにした。

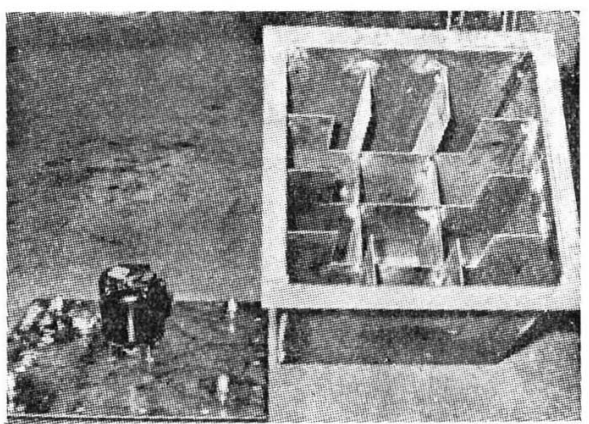

図 4 高速海水試験タンク

タンク内の海水の温度は実験中 $60 \sim 110^{\circ} \mathrm{F}$ の変化が あった。しかしこれは問題とは考えていなかった。もっ と激しい環境での試験ではもっと高温度の場合もある。 高温では溶存酸素が減少与るが，その影響は余りない。 
おそらく渦流が激しいので過飽和の空気を常に含むこと になるためであろう。

この高速試験は 30 日以上続けた。平均の金属腐食量 は最初の厚さの約半分位に達し, しかも一様なものでな かった。電気的な測定は行なわなかったが，肉眼で調べ た範囲ではプラスチックの層膜の劣化などはどこにもな かった。つまりプラスチックの材質や加工法に対しては 実用実験で少しも心配がないことがわかった。

上記 30 日の試験では最終決定を見たものと同様の形 状を有し，回転円板に用いたのと同一の材料と方法で構 成されている 3 個の短册形試験片を試験タンク内の海水 に浸漬した。これらの試験片は腐食を電気抵抗によって 測定するための結線はしてある。各試験片はタンク内で 深さを変えて異なる溶存酸素量下の試験をまねした。試 験片 No. 1 は底に垂直に置き, No. 3 は水面で半ば浸 漬して置いた。前に述べた回転板は海水を激しく攪捧し た。腐食は 3 試験片の各々につき試験期間中定期的に測 定を行なった。図 5 はその測定記録である。気液界面の ものが一番激しく腐食している。また選定した試験片の 厚さ 0.02 in はこのような使用状況で十分 1 力年の使用 に耐えることを示している。

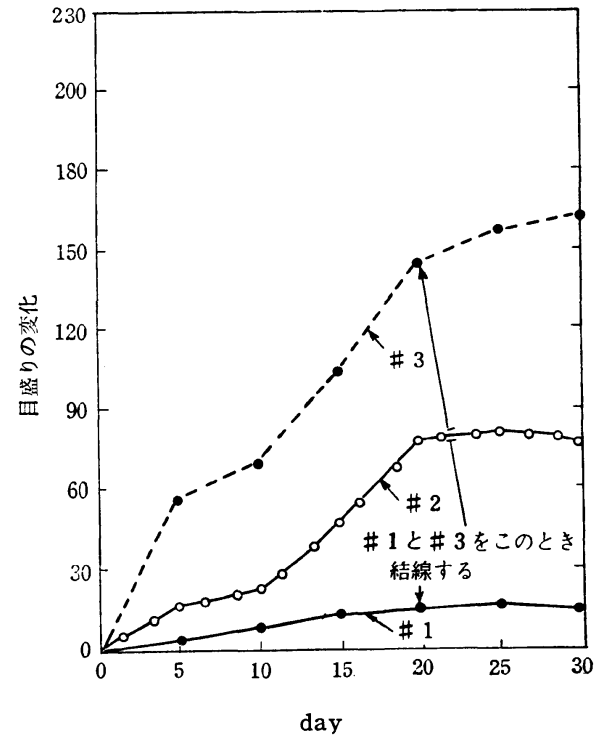

図 5 三つの軟鋼船体外板用試験片の海水中試験

上記試験片は市販の圧延軟鋼製である。すべて予備試 験には薄い圧延材として入手し易い普通の鋼板材を使用 した。船体用鋼板として特殊鋼板を使うべきかも知れな いが，普通材料でも電気的腐食量測定方法の可能性判定 には十分役立つものと考えたからである。

短册形の船体用試験片一つを HY 80 鋼で造り，これ によって特殊鋼でも加工法に問題はないことを確かめ, 普通鋼と腐食程度に差異があるかを見た。厚さ約 0.02 in の板を 0.625 in の板から片面だけ研削後化学研摩し て造り，反対面は元のままとした。短冊形の試験片をこ れから切り出して元のままの面を露出させた。試験片は 図 1 の形とし，たえず海水を新鮮に保って，普通軟鋼試 験片との比較を試みた。試験方法は，海水をLong Beach (Cal.) の港から毎分 10 ガロンの速さで汲み, 25 ガロン入りの蓋のないタンクに上から落としこれを $1 / 2$ in 内径の管で放流させた。試験片はタンクの取入管 近くに置き，その表面を海水が激しく乱流となって洗う ようにした。

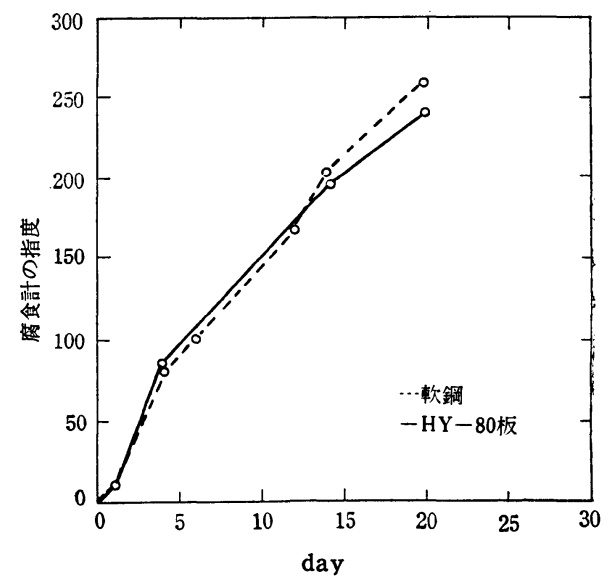

図 $6 \mathrm{SAE} 1010$ と HY 80 鋼の海水中の腐食の比較

電気的に腐食量を示す曲線は図 6 のように，両者の差 はほとんどないから軟鋼も高張力鋼も同じ材料から採取 したもの程度に似ていると考えてよい。

復水器用プローベ

熱交換器の復水器管の腐食もしばしば重大な問題とな る。管に孔があくと管内の液が管外の液を污すので絶対 に許るせない。この被害程度を測る方法がないため必要 以上に高価な材料を使うことになることが多い。

管端付近の腐食を減らす手段も今までもいろいろと研 究された。電気防食法は一応成功している。しかし復水 器を使用したままで，防食対策の効果を短い週期でたび たび測定する適当な方法がないことが研究の妨げとなっ ている。そのためにこの装置を工夫したのである。

要望されているプロ一べは最も腐食の激しい部分が示 す復水器管の腐食度を測れるものである。ほとんどの場 合まず腐食は管を管板に拡げた端部に起こる。この特殊 な腐食が測定できて使用者にあらかじめ警告を与えてく れるような計器の開発が望まれるが，これを使えば，流 速・温度・水質・電気防食などが各種の金属に及ぼす影 響を簡単に直接求めることができる。

このような試験片は適当に変更して管の入口付近やラ ツパ状の部分や，タンクから管に流出する部分など流速 
の变化により激しく腐食を生ずる個所の測定にも役立 つ。また固形物やガス流が管の腐食に及ぼす影響の監視 にも役立つ。流れに突然の攪乱が生ずる部分もしばしば 激しい腐食の生じ易い場所となる。

\section{復水器管用試験片の設計と構造}

ねらいは, 単独に製作して復水器管の入口に取り付け られるものを設計するにあった。結局できたのは図 7 の

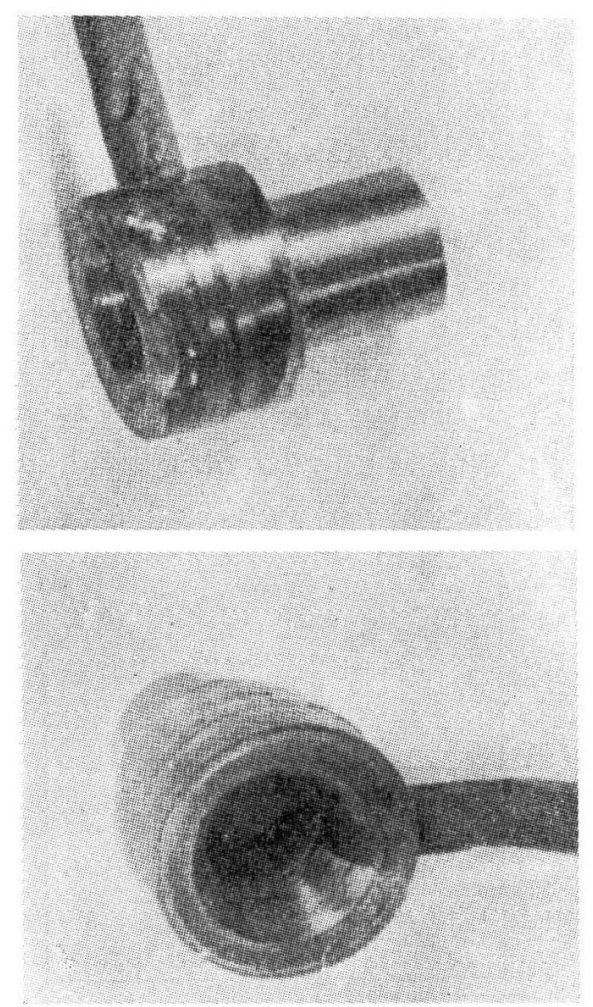

图 7 標準復水器管用試験片の外観

ものである。測定片は管の入Пの拡げられた所に極力似 せた形に造られた割れ目のはいった環である。これを適 当な形を使ってエポキシ樹脂に鋳込むことにした。肩付 きの金属さやを同時に鋳込んで叹付用管とした。この取 付管の外径を復水器管の内径と同じに造 り, 管に約 40 $\mathrm{mm}$ 位挿入する。取付管の材質は電池作用を避けるた め復水器管と同じ材質とし, その未端は面をとって液流 が取付管から復水器管へ自然に移るようにした。いまま でのところ外径 $5 / 8^{\prime \prime}$ ，肉厚 \#18の管に合わせたものだ けを造っている。他の寸法のものも別の鋳込形を造れば 同様に造ることができる。

取付管と復水器管の電気接続を確保するために, 両管 の表面は平滑でピッタリ合うものでなければなら奴。

市販の復水器管に渃干の寸法誤差がある上に端部は

* Crest Instruments 社の Corrosion Measuring Probe Model 203 Z-W 40
拡げてあるから，形が区々であって何か工夫をしないと 揃わない。それで特殊のリーマー装置を工夫して管の内 面を削ることとしたがその量はきわめてわずかである。 この試験片構造は性能にも取付方法にも不具合な点は子 想されず満足に使われている。測定片への電気接続には 適当な外装を施したケーブルを水室中の水中を経て, 耐 圧ブッシングの外側の “さし込み”まで導く。このブッ シングは通例, 手入れ孔の平らな蓋に設ける。

温度や電圧の影響を補正する照合抵抗片は, 温度計插 込部のような形をした別体とした。このためにプローべ の主要部分（管に㨂入する部分）は著しく小型で簡素化 されたものとなった。電線の取り出しは測定片と同じも のにして, これと並べて取り付ける。計器の読みはこの 二つの“さし込み”に線をつないで読む。ケーブルを長 くして熱交換器から離れた場所で計器を読むこともでき る。

\section{管用プローベの試験と評価}

プローべを管の端に取り付けるので，他の管とは流れ の様子が変ってくること, 管の内径が減少しているため 流量が減ることなどが予想されるが, 試験の結果流れの 様子には変化はなく, 試験片中の流速の増加によりわず かに腐食が激しくなる程度であることがわかった。

定性的に装置の感度を確かめるため, 実際によく見ら れる局部腐食に似せて硝酸を滴下させて局部腐食を造っ てみた。その結果, この試験片と測定装置で十分にこの ような局部腐食が測定できることがわかった。

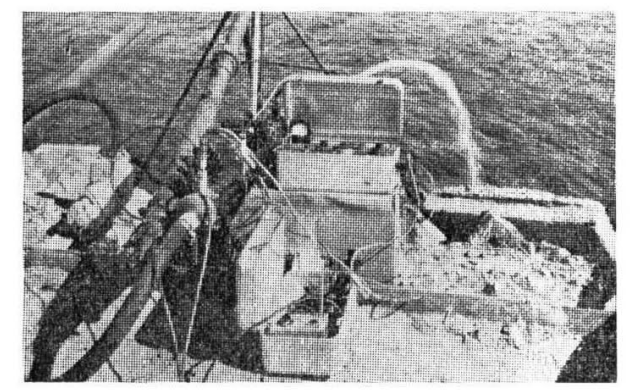

図 8 単管熱交換器を模した復水器管用試験片の試 験装置

実用試験に似せた試験を図 8 のような装置で試みた。 ポンプを使って問題の管の細い所で $20 \mathrm{ft} / \mathrm{sec}$ 位の流速 を与えた。

実用に供した形の最初のプローべは軟鋼である。これ を管端に挿入してリード線はパッキン・グランドから取 り出し, 測定は外部で行なった。比較のため入口側にこ の試験片を取り付けた管の出口側に標準形の針金環状プ ローべ*を設置した。従って流速は両者同一である。図 9 の上の 2 曲線がこの結果を示す。本プローべは針金形 の 3 倍も腐食することがわかる。この価を延長すると針 


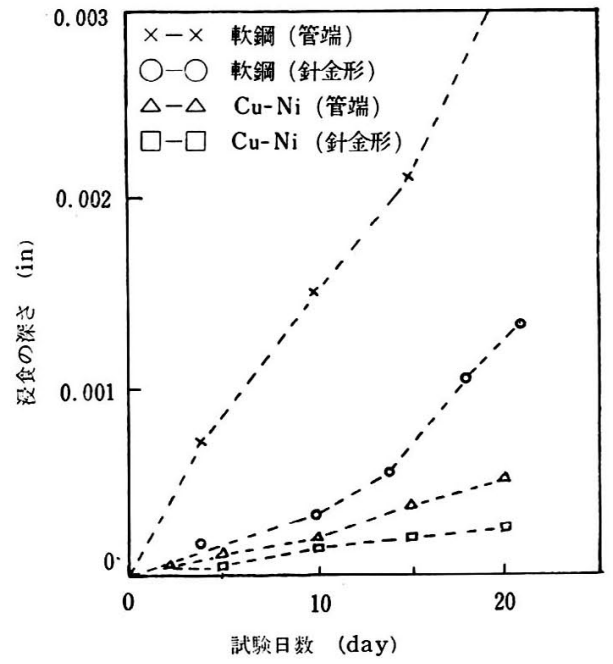

図 9 復水器管用試験片による試験結果

金形は 1 年に $0.020^{\prime \prime}$ ，この試駼片は $0.060^{\prime \prime}$ 消耗する ことになる。この实䮖絬果から，この試験片の形式は管 の局部腐食を示すのに役立つことがわかる。

いま一つ似たような試験を 70-30 Cu-Ni 合金で行な つた。結果は図 8 の下の二つの曲線であって軟鋼の場合 の約 $1 / 6$ の腐食量となっている。針金状試駼片はこの 試験片の約半分の值を示した。金属とプラスチックの境 界部の喰い込みや管に挿入した所の隙間腐食はなかっ た。彷って，全体として設計も工作も完全に満足なもの であったことが証明された。

円盤プローベ

このほかにたとえば隔壁の裏側，管やポンプの内 部, タンクとタンクの間の空室などの近奇り難い場所, 㹟い場所などに使い得る形式のものも必要である。

このような場所に使用できる標準形構造のプローべが あれ行に立つことが多い。

\section{円盤プローベの設計と構造}

これは比較的小さな平らな测定片をある決められた点 に押入できるようにしたもので，管の先端にこれに直角 に平円盤を取り付けてこれを测定片としている。円盤の 直径は自由に選べるが，陝い場所や細い管にも使えるよ う円盤の直径を $1 / 2^{\prime \prime}$ ，捕入する管の直径を $5 / 8^{\prime \prime}$ とした。 計測片も照合試験も同じ板から切り出し, リード線タ ップをつけて取付管に嵌め込めるように曲げて管に入れ エポキシで固めた。管の材料は適当な金属や仓成樹脂で もよいが，強さと耐久性を考光てステンレス鋼を選え だ。管の全長 6" のもの最初に予備試駼に使った。

装借方法を土夫して取り付ける深さは自由に外から調 節できるようにした。これには Dayton の Lenz 社製 胴体取付用ブッシュが具命がよかった。これは図 10 に 示すもので，管を挿入して，O-リングで気密を保ち二

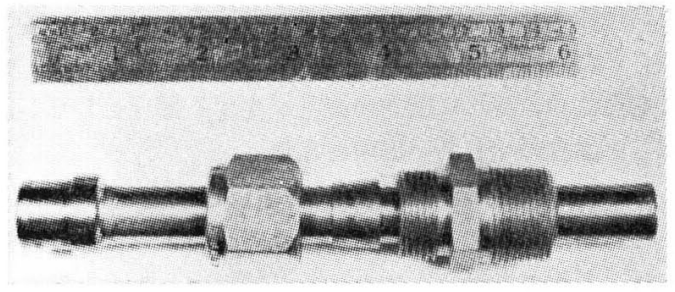

図 10 円盤形試験片 (Lenz 形調節觋付)

つ制のテーパー環をナットで締めて固定するものであ る。

\section{円盤プローベの評価}

測定片の形が風変りなため, この比較的小さなリード 線との接続部から試験片に供給される電流が均等に分布 するかどうかに疑問があった。これを確かめるため孔の ない円板を有する軟鋼測定板および中央に $1 / 8^{\prime \prime}$ の孔を 設けた川板を有する軟鋼測定板とを造りこれらを性能 の判明している慓準形電父抵抗式試験片とともに希硝酸 に浸して比䡆してみた。

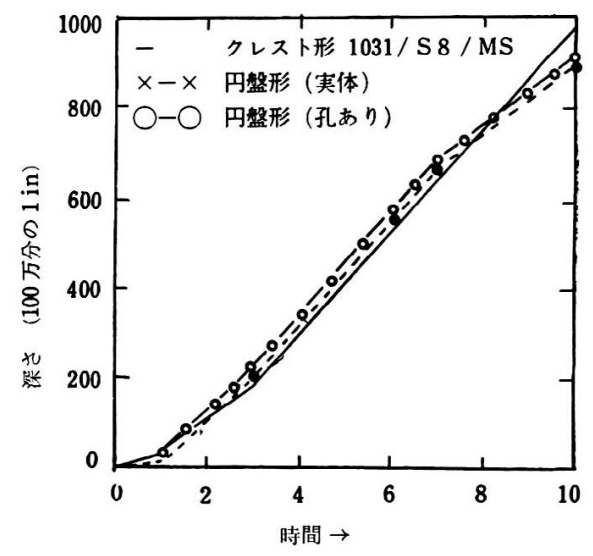

図 11 各種形状, 円盤形試験片成績の比較

図 11 はその絬果を示すもので，この 3 者の示す価は 実験誤差範囲で全く同じといえる。

最初の実用実験は軟鋼試験片を海水ポンプの吸入側に 取り付けたもので, 流速約 $2 \mathrm{ft} / \mathrm{sec}$, 試験片の厚さ $0.010^{\prime \prime}$, 計測器の感度は $5 \mu$ in の厚さの变化を示すも のである。このような状況で 20 日以上の試験で腐食度 $140 \mu \mathrm{in} / \mathrm{day}$ が得られた。これは $0.058^{\prime \prime} / \mathrm{yr}$ の腐食度 に当たる。適当な比較すべき資料はないが，この值はま ず実際に近いものと考えてよさそうである。試騟片の取 扱上の不具们は何もなかった。

\section{結論}

船舶用に適した現場で直接電気抵抗方式で連続的に測 定可能な腐食測定用試験片を考案した。

一つは船体外側用，一つはよく似た满造で船内のタン ク, ビルジ, 船倉, 構造物その他比較的広い面積のとこ 
ろに適したもの，一つは管内部や，小さな空所に適した もの，いま一つ腹水器管の入口や，タンクや太い管か ら細い管に移るところに適したものである。

その作動機能を実験室と実地によく似せた状況とで確 かめた。必要に応じて関連性ある他の測定法も加えた。 その結果船舶の腐食に関する諸資料と比較してみても十 分信頼し得る正確な測定結果が得られることが明らかに なった。

以上の結果からこの試験片は他の用途にも広く利用で きることがわかる。腐食を常時監視する場合, 電気防 食, 塗装, グリ一ス, 化学的防食などの防食対策の効果 を与えられた環境で比較する場合などに利用できる。新 しい防食対策の効果を研究するときの道具ともなる。キ ヤビテーションの判定や新しい構造材料の評価にも役立 つ。環境が材料に及ぼす影響を実地に確かめる場合にも 役立つ。

なおこの研究は米海軍艦船局の援助によって行なわれ たものであるが，上記結論は筆者達の私見であって軍に は関係のないことをお断りしておく。

\section{質疑応答の要旨}

1）温度差の影響について：試験片と照合用試験片が 同じ温度でないと誤差が出る。0.004" の軟鋼を蒸留水
中で $75^{\circ} \mathrm{F}$ から $80^{\circ} \mathrm{F}$ に急に変えると途中で $5 \mu$ in 位 の誤差を生じ，時が経つと戻る程度である。

2) 復水器管を試験したと.きの流速について：約 $1,200 \mathrm{ft} / \mathrm{min}$ 位である。

3）歪の影響について：できるだけ歪の起こらぬよ う，その影響を受けないように装備している。昰による 抵抗の変化は，普通はるかに高い歪を受けたときの歪測 定に使うものである。

4) 温度の修正と同様王の修正も必要ではないか：非 常に大きな影響を受けるときは必要となるが，この装置 にはその修正は工夫されていない。

\section{引用文献}

1) R.S. Capp \& B. J. Philibert: Corrosion, 16, 22 40 (1960) July

2) G. A. Marsh \& E. Schaschl: Oil \& Gas J., 54, No. 29, 135 142 (1955) Nov.

3) A. Dravnieks \& A. J. Freedman: Petr. Ref., July (1958)

4) E. C. Winegartner: Corrosion, 16, 99 103 (1960) June

5) G. H. Rohrback: Paper presented before the Sixth Western Regional Division Divisional Conference of NACE, Long Beach, California, Nov. 15 \& 16 (1956)

6) G. A. Marsh \& A. V. Koebley. Jr.: Oil \& Gas J., 54, No. 29, 139 (1955) Nov.

7) G. A. Marsh \& E. Schaschl: Corrosion, 14, $155 \mathrm{t} \sim 158 \mathrm{t}$ (1958) Mar.

\section{化学装置に適用した陰極防食の 3 例*}

化学工業における腐食環境は一般に陰極防食の適用に 適しないが，ときには陰極防食が最良の方法である場合 もある。本文に引用された 3 例は陰極防食が有効な手段 であった場合の説明である。これらは他の防食法が不成 功であったり，あるいはあまりに高価であった問題の解 決に陰極防食が有利であることを示した例であある。こ の 3 例はニッケル軟鋼およびステンレス鋼についてのも ので，各々がそれぞれ他とは相当に異なる問題である。 第一のものは製品の污損問題，第二は有機酸による腐食 問題，第三は粒界腐食問題である。

\section{ニッケルによる製品の污損}

一般に高純度の八ロゲン塩類の結晶を作るのに用いら れている陶器レンガで内張りされた鋼製タンクは腐食問 題では十分満足すべき成績を示している。しかしタンク から手で結晶をすくい出す際に陶器内張りの一部が製品

* 訳者：福谷英二 (中川防蝕工業)

** Dow Chemical Co., Michigan

(原文) Three Application of Cathodic Protection for Chemical Equipment. Mat. Prot., Vol. 1, No. 2, 26 32 (1962) Feb.

\section{H. W. Schmidt** \& A. A. Brouwer**}

と一諸にすくい出されることがしばしばある。これを防 止するためタンク内張りの代用材としてニッケルが選定 された。しかし操業の際ニッケル内張りに接している結 晶が緑色に変色し，ニッケル表面に沈殿物が見られた。 $\mathrm{X}$ 線回折の結果, この沈殿物は水に比較的不溶性で塩基 性炭酸ニッケルを主とするものであることが判明した。 乾燥した結晶では緑色から黒色の酸化ニッケルの点に変 わり製品を污損する。良好な製品を確保するためには緑 色の結晶を手で取り除く必要がある。正確な侵食の機構 はわからないが, 微量の酸化性の強い無機質の物質があ った。腐食度は低かったが重要な点は製品の污損であ る。製造工程は $100^{\circ} \mathrm{C}$ の飽和した液体が結晶鍋に流入 し, そこで常温に冷却される。約 3 日後母液を排除し結 晶を取り出して炉で乾燥する。

\section{1. マグネシウムの試用}

対策として陰極防食の採用を考えるとき留意すべきこ とは, 陽極反応生成物による製品の污損は許されないこ と, 不溶性の電極は八ロゲンガスを発生してニッケルを 侵すので，かえって製品を污損することなどである。マ 